NASA Technical Memorandum 88967

AIAA-87-1788

\title{
Full-Scale Thrust Reverser Testing in an Altitude Facility
}

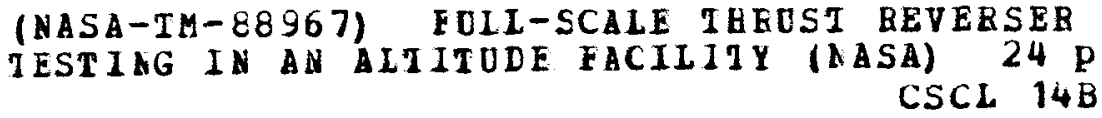

N87-1E5T5

Unclas

G3/09 43643

Charles M. Mehalic and Roy A. Lottig

Lewis Research Center

Cleveland, Ohio

Prepared for the

23rd Joint Propulsion Conference

cosponsored by the AIAA, SAE, ASME, and ASEE

San Diego, California, June 29-July 2, 1987

\section{nush}




\title{
FULL-SCALE THRUST REVERSER TESTING IN AN ALTITUDE FACILITY
}

\author{
Charles M. Mehalic and Roy A. Lottig \\ National Aeronautics and Space Administration \\ Lewis Research Center \\ Cleveland, Ohio 44135
}

\section{Abstract}

A two-dimensional convergent-divergent exhaust nozzle designed and fabricated by Pratt and Whitney Aircraft was installed on a PW1128 turbofan engine and tested during thrust reverser operation in an altitude facility at NASA Lewis Research Center. A unique collection system was used to capture the thrust reverser exhaust gas and transport it to the primary exhaust collector. Tests were conducted at three flight conditions with varying amounts of thrust reverse at each condition. Some reverser exhaust gas spillage by the collection system was encountered but engine performance was unaffected at all flight conditions tested. Based on the results of this test program, the feasibility of altitude testing of advanced multi-function exhaust nozzle systems has been demonstrated.

\section{Introduction}

Operational requirements of the next generation of military aircraft will dictate the use of advanced multi-function exhaust nozzle systems capable of thrust vectoring and reversing. Previously, thrust vectoring provided power assist during short or vertical takeoffs while thrust reversing was used for ground roll reduction. The advanced nozzle systems currently under consideration will be used to enhance aircraft performance by combining aircraft aerodynamic control with nozzle propulsive control to provide increased inflight maneuverability. While testing for the previous applications of thrust vectoring and reversing only required sea-level test stands, advanced nozzle systems will require testing under simulated altitude conditions.

Several concepts for multi-function nozzles have been devised and fabricated. 1 Many of the concepts include separate exhaust streams for vectoring and reversing. While the vectored thrust exhaust may be handled in an altitude facility in a manner similar to previous tests with axisymmetric nozzles, the requirement to collect the reverser exhaust presents a unique problem. The supersonic reverser exhaust gases must be turned and routed to the primary exhaust gas collection system without creating adverse effects on engine performance or the test cell environment. Recently, computational fluid dynamics has been applied to the problem of designing exhaust gas collection systems for altitude testing of vectoring/reversing exhaust nozzle systems. $2-3$ These studies indicated that reverser exhaust gas collector ducts without internal vanes would be inadequate to provide satisfactory collector system ejector performance because of impingement on the outer wall with resulting flow reversal and spillage at the reverser portl collector duct interface. The exhaust gas collection system used for the tests described in this paper included turning vanes in the collector ducts to turn the flow and prevent reverse flow caused by impingement.
This paper describes the hardware and discusses the full-scale tests of a two-dimensional convergent-divergent ( $2 D / C D$ ) exhaust nozzle during thrust reverser operation in an altitude facility at NASA Lewis. These tests were conducted as part of a joint NASA/Air Force/Pratt and Whitney program to test a 2D/CD nozzle in an altitude facility and represent the first time that full-scale enginel thrust reverser operation was attempted in an altitude facility. For the testing, the nozzle, a PW1128 turbofan engine, and a unique system designed and fabricated specifically for collecting the reverser exhaust gas were installed in the test ce11. Thrust reverser operation was demonstrated at three flight conditions. At each flight condition the amount of thrust reverse, defined as percent of thrust reverser port open area, was varied from 0 to 100 percent at several enqine power settings ranging from idle to maximum nonafterburning power. Results are presented to document the performance of the reverser exhaust gas collection system and verify the feasibility of performing this type of testing in altitude facilities.

\section{Nomenclature}

$\begin{array}{ll}\text { Alt } & \begin{array}{l}\text { altitude, } \mathrm{m} \\ \mathrm{F}\end{array} \\ \text { FTIT } & \text { fhrust, } \mathrm{N} \\ \mathrm{N} & \text { rotational speed, rpm } \\ \mathrm{P} & \text { pressure, } \mathrm{N} / \mathrm{m}^{2} \\ \mathrm{~T} & \text { temperature, } \mathrm{K} \\ \mathrm{W} & \text { flowrate, } \mathrm{kg} / \mathrm{sec} \\ \delta & \begin{array}{l}\text { ratio of total pressure to absolute } \\ \text { pressure of } \mathrm{NACA} \text { standard sea-level } \\ \text { conditions }\end{array}\end{array}$

$\theta$

ratio of total temperature to absolute temperature of NACA standard sea-level conditions

\section{Subscripts}

a

g

no reverse

$\mathrm{s}$

spillage

$t$ air

gross

without thrust reverser operation

static conditions

condition of reverser exhaust gas spillage into test cell

total conditions

airflow measuring station 
compressor exit

\section{Apparatus}

\section{Facility}

The test program was conducted in one of the two altitude chambers of the Propulsion Systems Laboratory (PSL) at NASA Lewis. Each test chamber is $7.3 \mathrm{~m}$ in diameter and $11.9 \mathrm{~m}$ long. Conditioned air at the proper pressure and temperature to simulate the desired flight condition is supplied by ducting through the forward bulkhead to the engine inlet while the desired altitude pressure is maintained in the test chamber.

A photograph of the test installation is shown in Fig. 1. The engine was mounted on a multi-axis thrust stand with a flexible seal between the inlet air ducting and the engine to provide accurate thrust measurement while accounting for engine growth and movement. The effective area of the seal used to correct the measured gross thrust was determined from pre-test thrust stand calibrations. A gap of approximately $1.9 \mathrm{~cm}$ was maintained between the nozzle reverser ports and the fixed reverser collector ducts to attempt to avoid any effects on the thrust measurement.

\section{Engine}

The engine used for the thrust reverser tests with the 2D/CD nozzle was a Pratt and Whitney Aircraft PW1128 low-bypass, high-compression ratio twin-spool afterburning turbofan. This engine consists of a three-stage fan driven by a two-stage turbine, ten-stage compressor driven by a two-stage air-cooled turbine, an annular combustor and a mixed flow augmentor. The augmentor was not used during the thrust reverser testing. Research instrumentation was installed in the engine to measure static pressure, total pressure and total temperature at the engine inlet, fan discharge, compressor inlet and exit, and fan turbine inlet and exit to monitor engine performance during the tests.

\section{0/CD Nozzle}

The 2D/CD nozzle has a circular inlet section that transitions to a rectangular cross section nozzle with rigid sidewalls and moveable upper and lower horizontal flaps that control throat area, exit area, and thrust direction. The flap positions for axial, partial reverse, and full reverse thrust operation are shown in Fig. 2. The upper and lower convergent flaps pivot about rigid shaft supports and determine the convergent exhaust area in the axial thrust mode and the percent reverse thrust in the reverse thrust mode. These flaps are synchronized with external connecting links. As the convergent exhaust area is reduced the reverser ports open to maintain total discharge area approximately constant.
The divergent flaps are attached to the convergent flaps and set area expansion ratio and thrust vectoring up to a maximum of $20^{\circ}$ from the horizontal. In the axial thrust mode the upper and lower divergent flaps are positioned symmetrically; in the vectored thrust mode one flap acts as a deflector to vector thrust.

The nozzle was actuated hydraulically and had a control system to provide manual control of the thrust reverser position at engine power settings up to intermediate. Thrust reverse with afterburning was not permitted. This control system also allowed manual setting of vector angle and nozzle area expansion ratio. During normal forward thrust operation the nozzle control scheduled throat area as requested by the Digital Electronic Engine Control (DEEC). A more detailed description of the 2D/CD nozzle design and its operation during sealevel tests is contained in Ref. 4 .

Reverser Exhaust Collection System

The reverser exhaust qas collection system consisted of two uncooled rectangular cross section ducts constructed of $0.48 \mathrm{~cm}$ stainless steel to capture the reverser exhaust and transport it to the primary exhaust collector, support hardware for the ducts, and a conical adapter section to the primary exhaust collector. The installation of this hardware in the test cell is shown in Fig. 3 . The support structure held the reverser collector ducts over the reverser ports so there was no contact between the nozzle and ducts (a gap of approximately $1.9 \mathrm{~cm}$ was maintained at the nozzle/duct interface). At the discharge of the ducts a sliding seal between the ducts and a cover plate on the conical adapter (Fig. 4) was installed to eliminate exhaust gas recirculation. The cover plate on the conical adapter had three rectangular openings to accommodate the reverser exhaust (top and bottom) and the nozzle exhaust during forward and partial reverse thrust operation.

A schematic drawing of a reverser collector duct is shown in Fig. 5. A limited amount of aerodynamic instrumentation was installed on the turning vanes internal to the duct. Details of the instrumentation mounting are shown in $\mathrm{Fiq} .6$. In addition to the instrumentation of Figs. 5 and 6 , air temperatures were measured near the area of the gap between the ducts and reverser port openings on each side of the installation to determine if exhaust gas spillage occurred during reverser operation. These thermocouples were mounted approximately $20 \mathrm{~cm}$ away from the nozzle in the plane of the reverser port/collector duct interface.

The primary consideration in the design of the reverser collector ducts was to have them operate over a wide range of conditions without adversely affecting engine nperation or test cell environment. Also considered was ease of construction which accounts for the extensive use of circular arc and straight sections. Since a limited amount of space was available between the engine centerline and the test cell floor $(1.8 \mathrm{~m})$, it was felt that supersonic turning of the reverser exhaust could not be accomplished $w^{i}$ thout compromising engine performance. Therefore, it was decided to reduce the Mach number of the exhaust gases below 
1.0 and turn the flow subsonically. The flow field in the area of the reverser ports was predicted using NAP code, a two-dimensional Euler code that handles both supersonic and subsonic flow and assumes no viscous effects. The design was based on a maximum expected reverser exhaust flow of $90.7 \mathrm{~kg} / \mathrm{sec}$ at $811 \mathrm{~K}$. Based on the analysis of the flow field, the first row of turning vanes was positioned approximately along a contour line of constant Mach number (2.0) with the intent of setting up a series of shocks to reduce the Mach number to subsonic downstream of these turning vanes. The exhaust flow could then be turned subsonically by the next two rows of vanes and transported to the primary exhaust collector. With the exception of the three rows of turning vanes, the remainder of the internal duct structure (stiffeners, ribs, and strengthening rods) was installed to strengthen the ducts to operate at pressure differentials up to $172.4 \mathrm{kPa}$ across the walls. Finally, upon installation, the outside of both ducts was covered with insulation to reduce thermal gradients in the duct structure and minimize heat loss to the test cell during thrust reverser operation.

\section{Procedure}

Thrust reverser operation was carried out at three flight conditions: $12192 \mathrm{~m} / 0.8 \mathrm{Mach}$, $7315 \mathrm{~m} / 0.8 \mathrm{Mach}$, and $9144 \mathrm{~m} / 1.17 \mathrm{Mach}$. At the $7315 \mathrm{~m}$ condition, engine inlet and test cell pressures were maintained at the correct values for altitude/Mach number simulation, but no attempt was made to supply the correct engine inlet temperature; ambient temperature (approximately $292 \mathrm{~K}$ ) was used. For the other flight conditions, the pressures and temperatures were those corresponding to the actual flight condition.

At each flight condition, the amount of thrust reverse, defined as percent of thrust reverser port open area, was varied from 0 to 100 percent at several engine power settings ranging from idle to intermediate (maximum nonafterburning power). For each test point, engine, nozzle, and test cell conditions were established as required, and the engine was allowed to stabilize at a steady-state operating condition prior to recording data. The data were acquired by recording 10 consecutive scans ( $1.5 \mathrm{sec}$ interval between scans) and averaging the individual measurements before performing final calculations. This approach provided average data rather than only one instantaneous set of data.

During the tests, CRT displays in the control room were used to monitor the test conditions, engine and nozzle performance, and condition of the test hardware. All measured parameters and calculations were available for monitoring and updated at 1.5 sec intervals. In addition, critical measurements were compared with programmed limits and any out-of-limit conditions were highlighted on the displays.

\section{Discussion of Results}

Results from the thrust reverser tests are presented to show the performance of the reverser exhaust gas collection system and its ability to gather the flow and transport it to the primary exhaust collector. The effect of the collection system on engine performance during thrust reverser operation is also examined by comparison of selected engine parameters between 0 and 100 percent reverse. The effectiveness of the thrust reverser to reduce forward axial thrust is presented for each flight condition tested.

\section{Reverser Collection System Performance}

The reverser exhaust collection system accomplished the task of capturing and transporting the reverser exhaust gas to the primary collector quite well at all engine power settings for reverser settings up to approximately 60 percent. At the higher reverser settings, exhaust gas spillage occurred at the nozzle/collector interface for all flight conditions tested. Figures $7(a)$ to $(c)$ show the spillage temperature ratio as a function of engine airflow for each test condition. The spillage temperature ratio is the average air temperature measured by the thermocouples in the plane of the gap between the nozzle reverser ports and collector ducts divided by the temperature measured without thrust reverse which was nominally $290 \mathrm{~K}$. The amount of reverser flow was not measured but the increase of spillage temperature ratio may indicate an increase of exhaust gas spillage as the amount of thrust reverse increases. During normal operations, test cell temperatures are maintained at or below $340 \mathrm{~K}$ with facility cooling air. For the reverser tests a constant test cell cooling flow of approximately $23 \mathrm{~kg} / \mathrm{sec}$ was used and thrust stand calibrations were performed in an attempt to account for drag forces induced by the cooling flow. To maintain local test cell temperatures below $340 \mathrm{~K}$ corresponds to a maximum spillage temperature ratio of approximately 1.2 in Fig. 7. At this ratio continuous reverser operation was possible at 60 percent and below. Above 60 percent reverse, some damage to instrumentation lines was experienced on a localized basis near the nozzlel collector duct interface.

Figure 8 presents an estimate of the flow field within the reverser ducts at the $7315 \mathrm{~m} /$ Mach 0.8 condition which is representative of all the conditions tested. Based on the limited internal reverser collector duct instrumentation which indicates local flow Mach numbers that may differ from the free stream because of the location of the static pressures on the vanes, it appears that the reverser flow (below 80 percent reverse) follows the contour of the wall with a region of low flow as indicated. At 80 percent reverse and above the highest Mach numbers entering the duct are at the center of the stream with low velocity (high pressure) flow near the fore and aft portions of the duct entrance. It is this low velocity, high pressure exhaust gas, probably caused by jet impingement on the internal surfaces of the reverser collector ducts that causes the increased spillage at large reverser settings. At the high reverser settings, the turning vanes may not be doing an effective job of turning the flow and impingement on the forward wall of the duct may be creating an area of backflow toward the duct inlet. Increasing the chord length of the turning vanes may help to alleviate the problem in future tests. Additional instrumentation is also required to more accurately define the flow field within the ducts. 
To substantiate the flow field estimate of Fig. 8, Fig. 9 indicates damage experienced by the strengthening rods internal to the duct. The staggered horizontal and vertical circular cross section rods were supported by welds at the ends. As the testing progressed, failure of the horizon$t a l$ rod welds caused by vibration occurred as indicated in Fig. 9. Both the top and bottom ducts experienced similar failure patterns indicating damage to those horizontal rods submerged in the high flow along the outer duct walls while rod welds in the low flow region near the inner walls did not fail. These failures could possibly be minimized in future collector duct designs by aerodynamically shaping the strengthening rods or providing some type of support at the center of the rods.

\section{Engine Performance}

As mentioned earlier, one of the prime considerations in the design of the collection system was to be able to collect the thrust reverser exhaust gas without affecting engine performance by creating an unusual backpressure condition. Figures 10 to 12 present comparisons of engine speed match, fan turbine inlet temperature, and $f$ an and compressor operating lines without thrust reverse and at 100 percent reverse. The figures indicate that over the range of flight conditions tested, the engine performance was not affected by thrust reverser operation or the reverser exhaust gas collection system.

\section{Measured Gross Thrust}

Thrust measurements during reverser operation were made using a multi-axis thrust stand. The thrust stand installation and calibration was similar to that described in Ref. 5. Figure 13 shows measured gross thrust corrected to engine inlet conditions as a function of nozzle pressure ratio for each flight condition tested. The effectiveness of the thrust reverser to reduce axial gross thrust is readily apparent from the figure. The largest reduction in gross thrust occurs in the steps between 0 and 80 percent reverse with only a small axial thrust reduction between 80 and 100 percent reverse.

The performance of the thrust reverser at 100 percent reverse is shown in Fig. 14. The figure indicates that measured reverse thrusts of 50 percent of intermediate forward thrust were obtained over an engine power level range from 50 to 100 percent. The good correlation of the data at the higher power settings indicates that reverse thrust performance was unaffected by the reverser exhaust gas collection system.

\section{Concluding Remarks}

The tests of the 2D/CD nozzle during thrust reverser operation successfully demonstrated the feasibility of full-scale altitude testing of advanced thrust vectoring/reversing exhaust nozzle systems and added significantly to the test experience of nonaxisymmetric nozzles. The hardware used to collect the reverser exhaust gas performed adequately over a wide range of engine operating conditions even though some reverser exhaust gas spillage into the test cell was experienced. This hardware also successfully satisfied the criteria that engine performance remain unaffected during thrust reverser operation.

Based on the results of these tests, the following recommendations are made for future testing of advanced vectoring/reversing exhaust nozzle systems in similar installations:

1. Longer turning vanes should be used to provide more effective turning of the flow and create a more equally distributed flow field in the reverser collector ducts.

2. Computational fluid dynamics should be used more extensively in the design of the reverser duct internal structure along with vibration analysis in an attempt to minimize any damage that may be caused by the flow through the duct.

3. Some type of seal arrangement should be used at the reverser port/collection system interface to minimize exhaust gas spillage without compromising thrust measurements.

4. Additional instrumentation should be installed in the reverser collector ducts to better define the actual flow field in the ducts.

\section{References}

1. Dusa, D.J., Speir, D.W., and Dunbar, D.K., "Multi-Functional Nozzles for Advanced Weapon Systems," Powered Lift Systems Plus, SAE SP-555, SAE, Warrendale, PA, 1983, pp. 9-19.

2. Phares, W.J., Cooper, G.K., Swafford, T.W., and Jones, R.R., "Application of Computationa 1 Fluid Dynamics to Test Facility and Experiment Design," AIAA Paper 86-1733, June 1986.

3. Crane, S.N., Jr., Jones, R.R. III, and Maywald P.V., "Exhaust Gas Management for Testing Vectoring and Reversing Turbine Engines," AEDC-TR-86-22, Aug. 1986.

4. McLafferty, G.H. and Peterson, J.L., "Results of Tests of a Rectangular Vectoring/Reversing Nozzle on an F100 Engine," AIAA Paper 83-1285, June 1983.

5. Wooten, W.H., Blozy, J.T., Speir, D.W., and Lottig, R.A., "Altitude Testing of a Fiight Weight, Self-Cooled, 2D Thrust Vectoring Exhaust Nozzle," SAE Paper 841557, 0ct. 1984. 
ORIGINAL PAGE IS

OF POOR QUIALITY

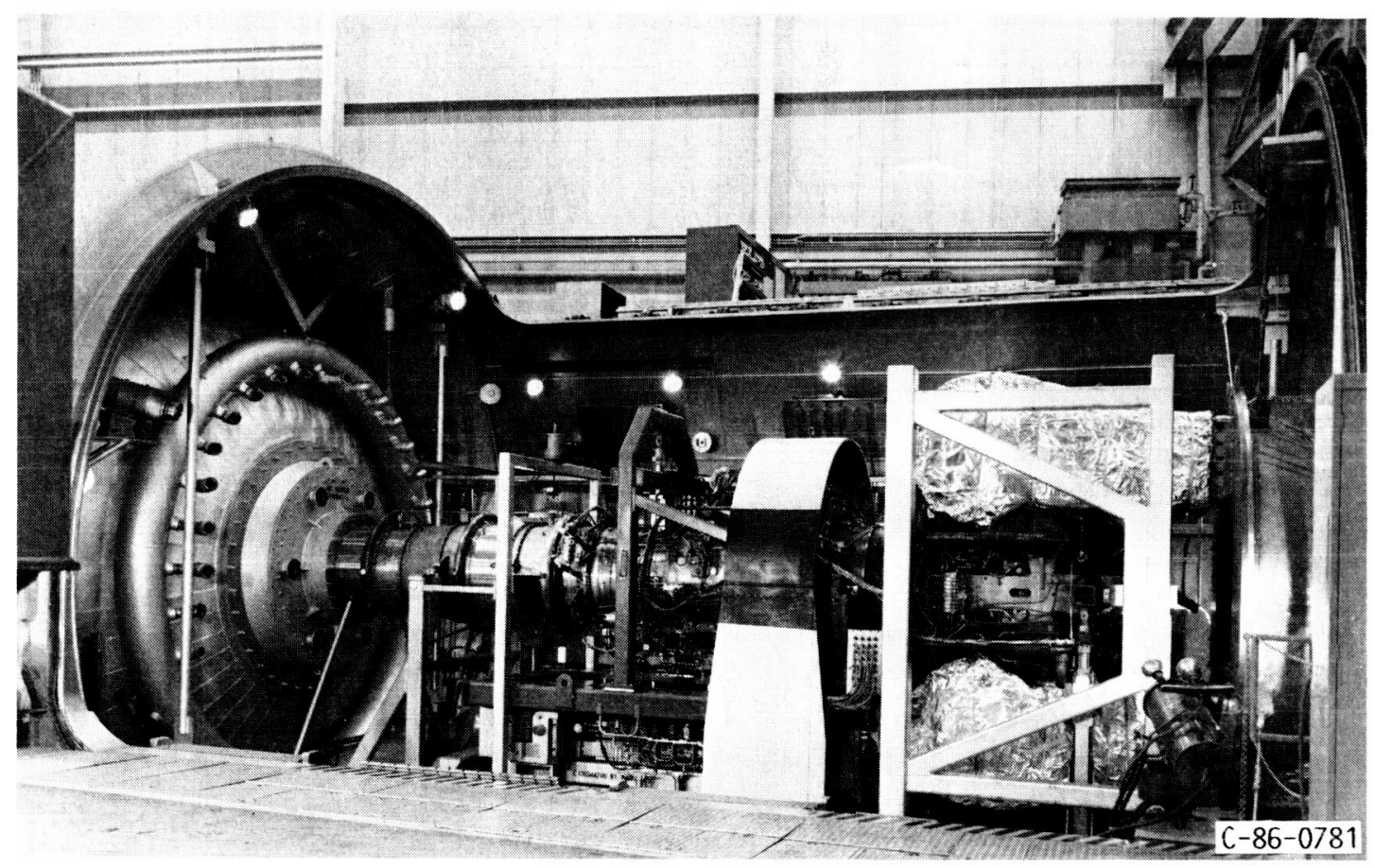

FIGURE 1. - INSTALLATION OF ENGINE, NOZZLE AND REVERSER COLLECTOR SYSTEM IN TEST CELL. 

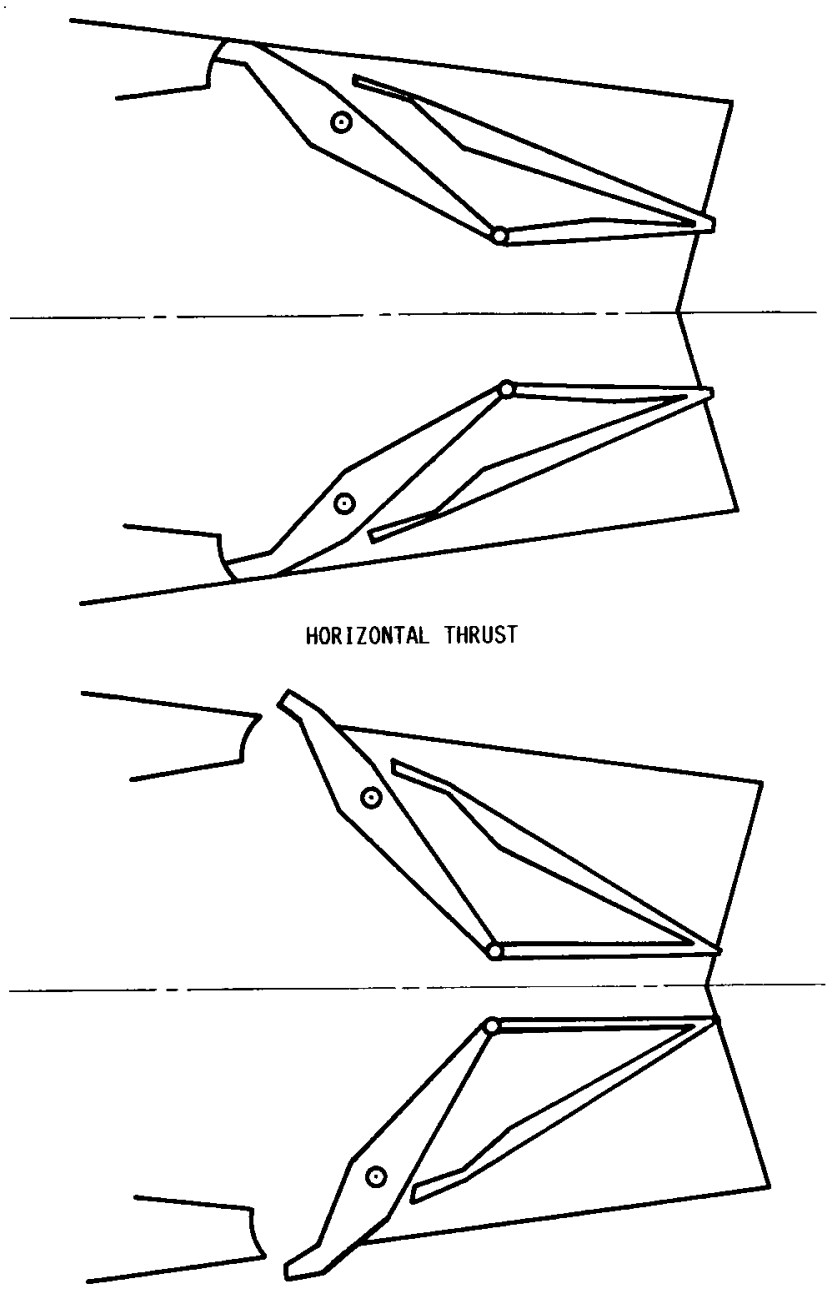

PARTIAL REVERSE THRUST

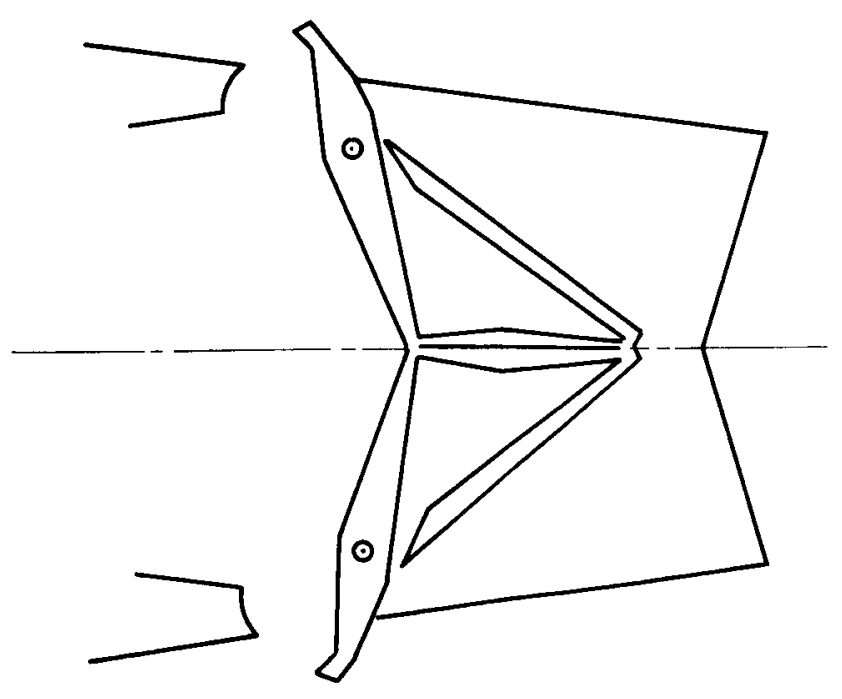

FULL REVERSE THRUST

FIGURE. 2. - SCHEMATIC OF 2D/CD NOZZLE OPERATION. 


\section{CRIGWAL PBES IS
OF POOR QUALITY}

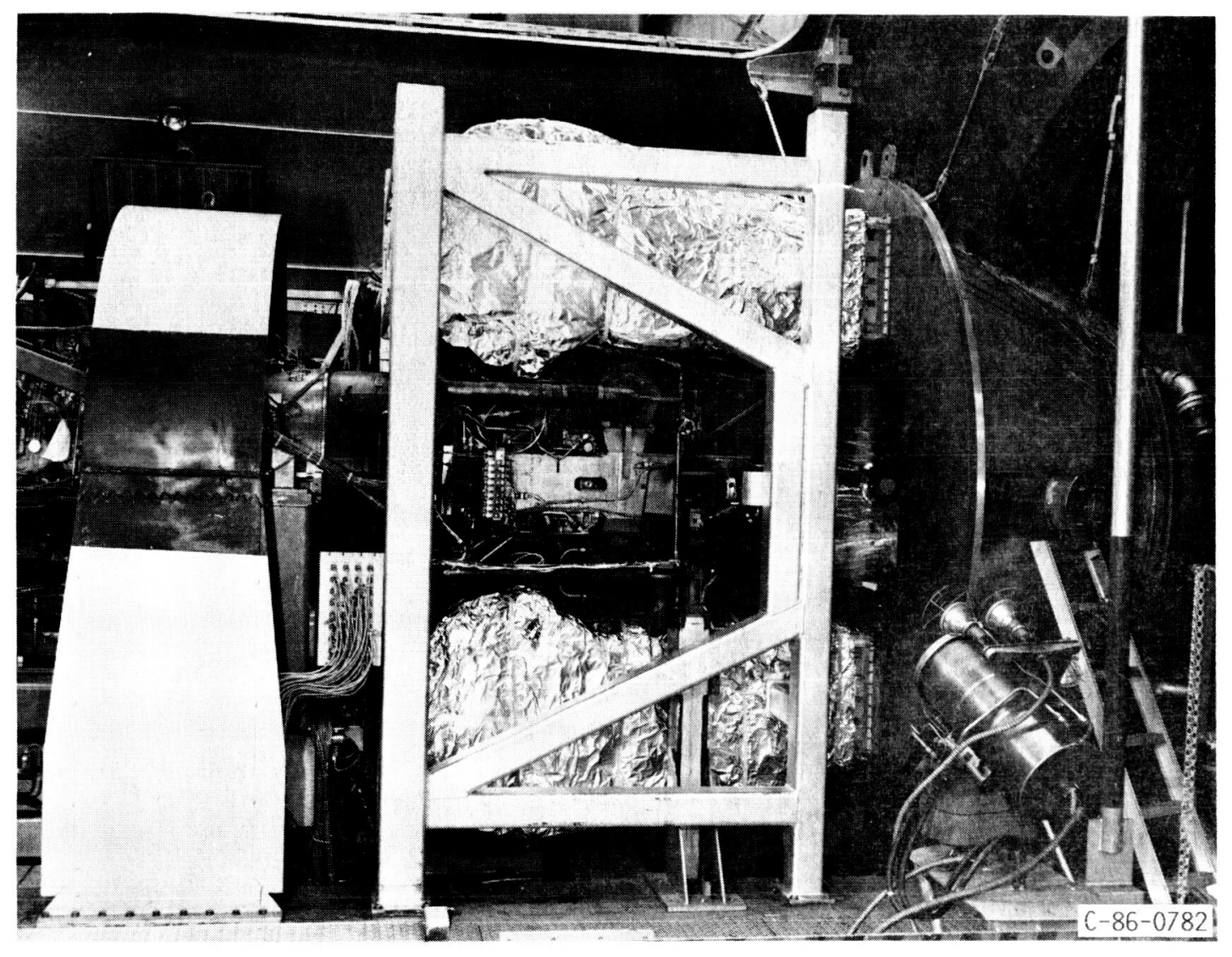

FIGURE 3. - REVERSER COLLECTOR SYSTEM INSTALLATION. 


\section{ORIGINAL PAGE IS \\ OF. POOR QUALITY}

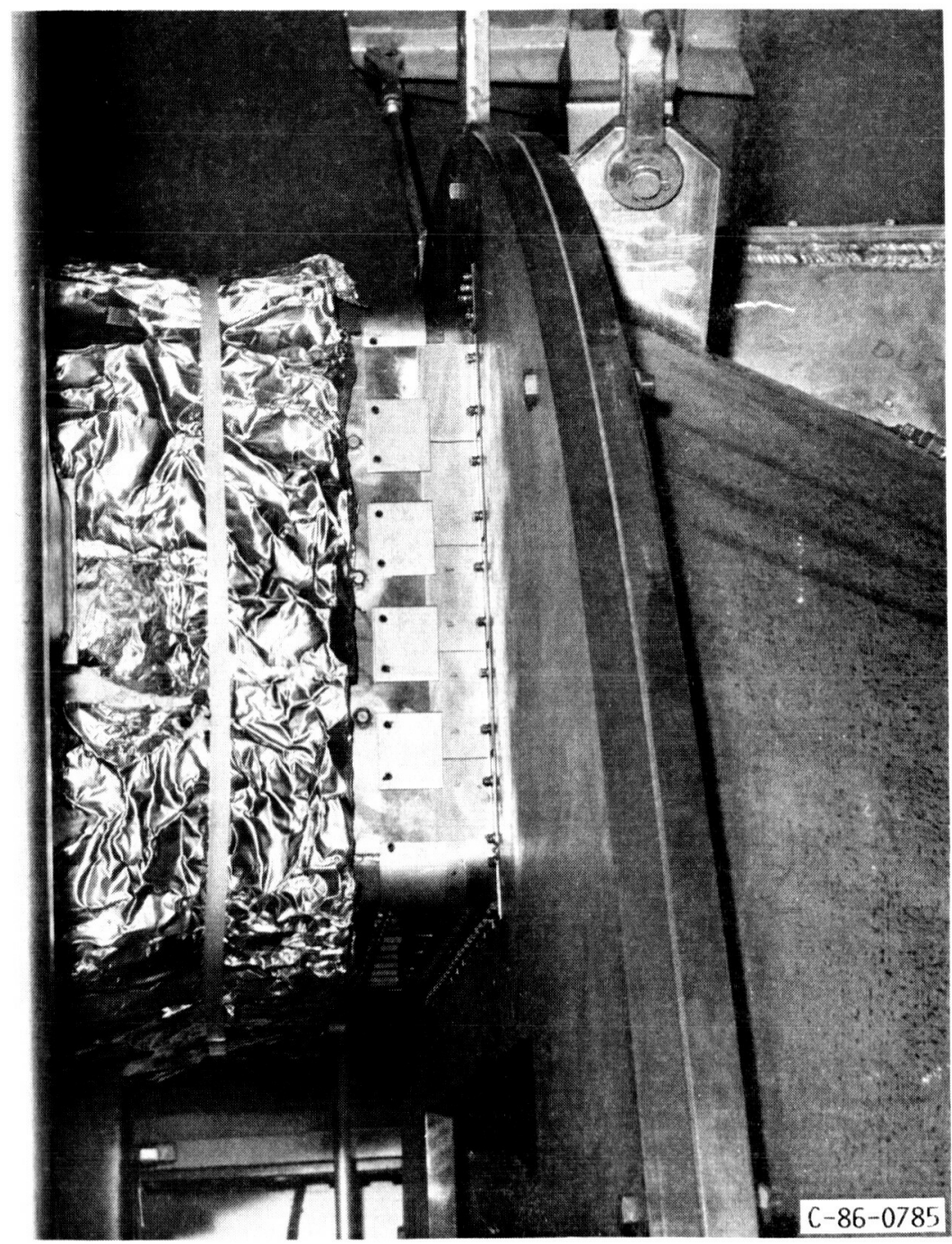

FiguRE 4. - SEAL BETWEEN REVERSER COLLECTOR DUCT AND CONICAL ADAPTER. 


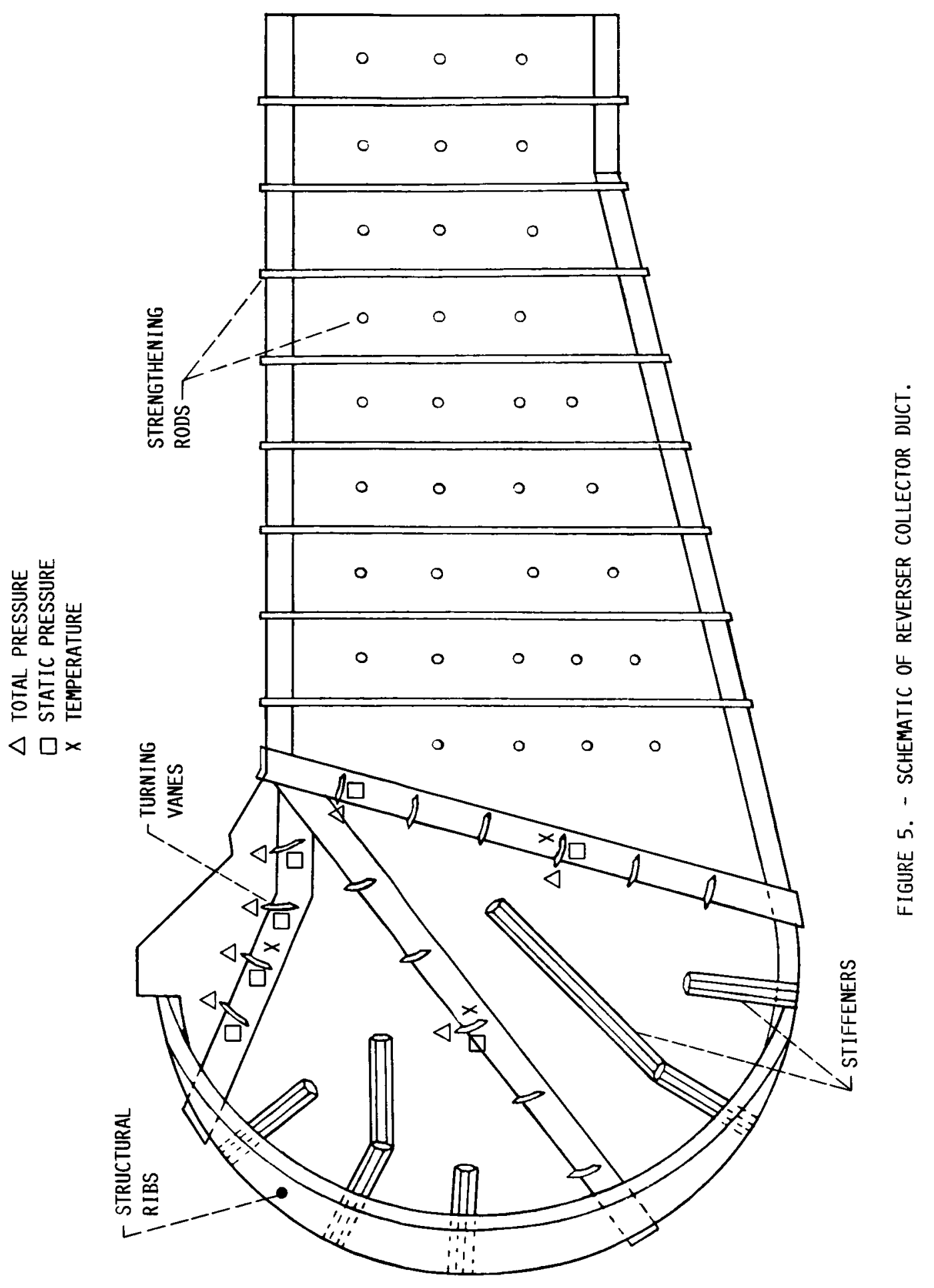



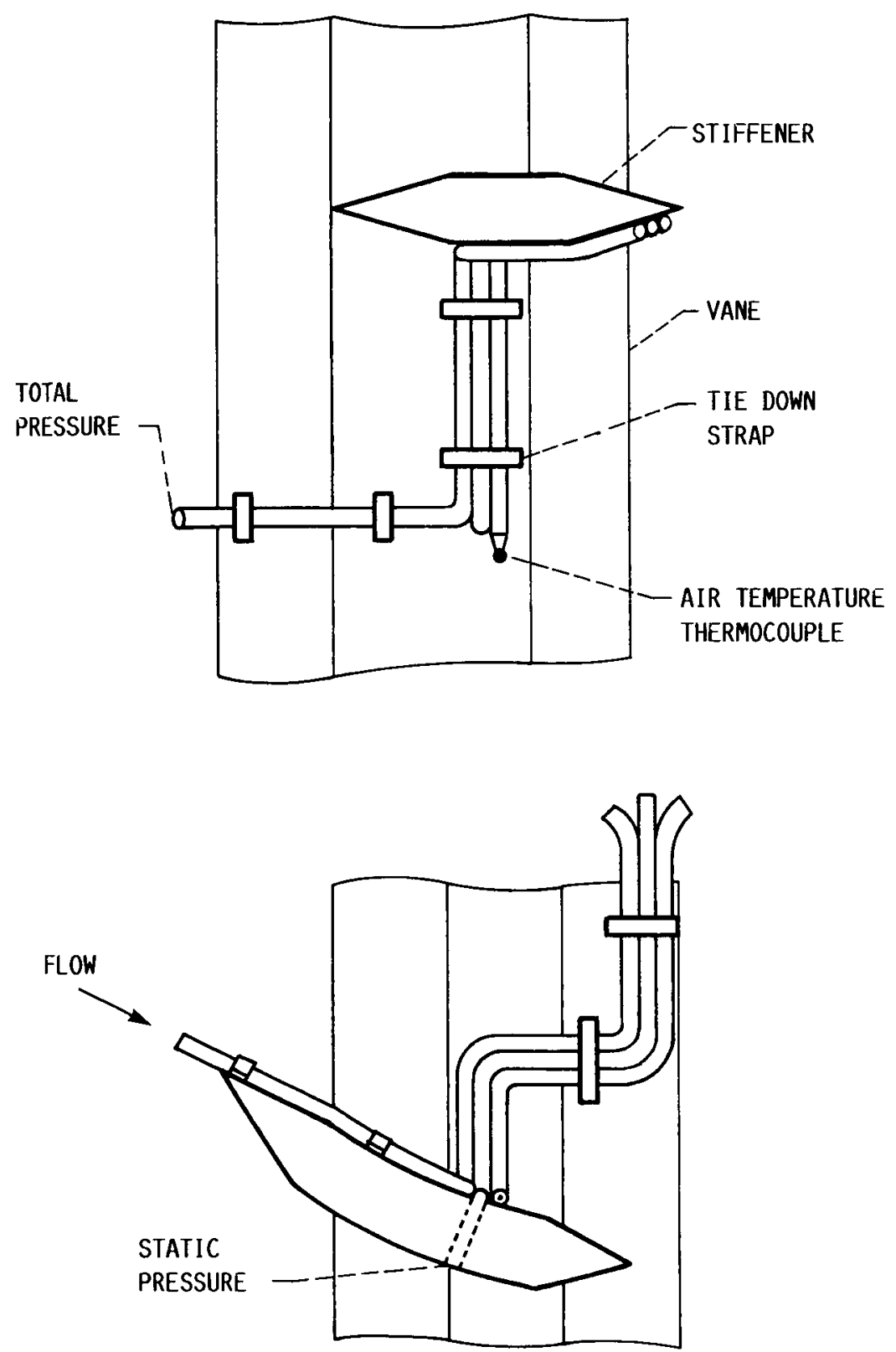

FIGURE 6. - DETAIL OF TURNING VANE INSTRUMENTATION INSTALLATION. 


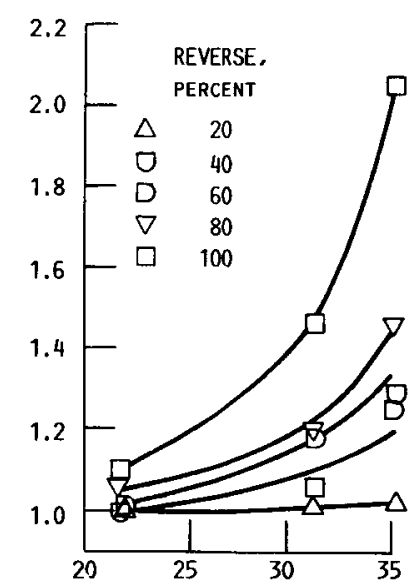

(A) FLIGHT CONDITION: $12192 \mathrm{M}$,
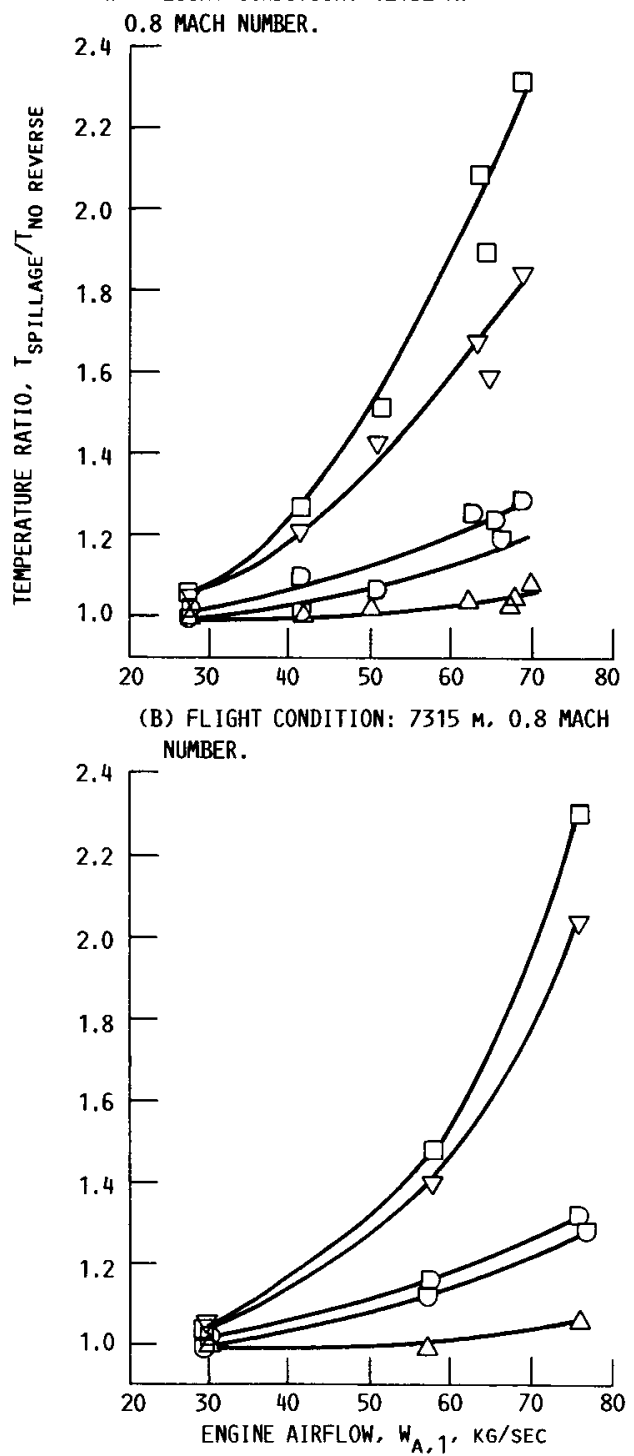

(C) FLIGHT CONDITION: $9144 \mathrm{~m}, 1.17$ MACH NUMBER.

FIGURE 7. - EFFECT OF REVERSER OPERATION

ON TEST CELL TEMPERATURES AS MEASURED

BY THERMOCOUPLES IN THE PLANE OF THE RE-

VERSER PORT/COLLECTOR DUCT INTERFACE. 


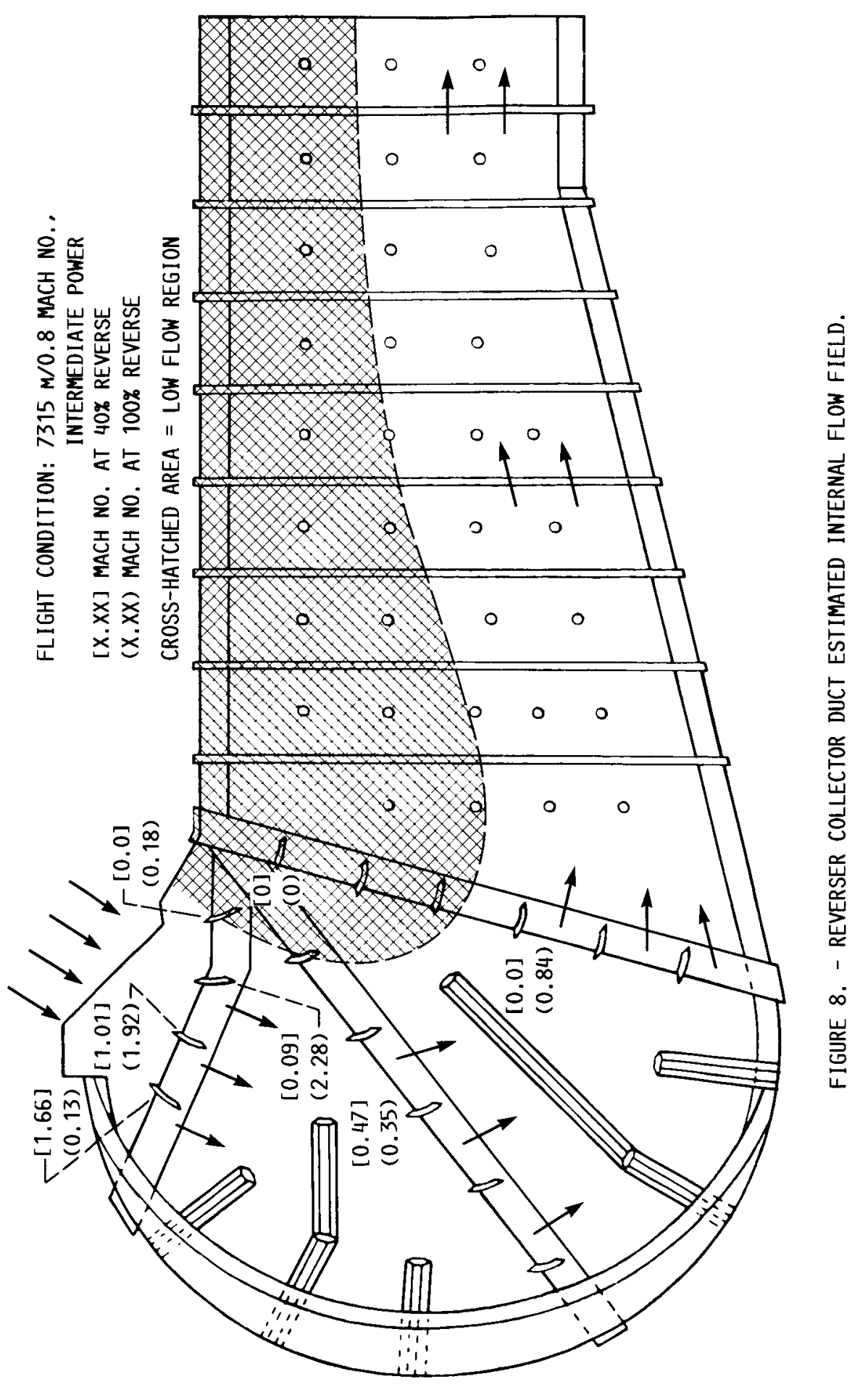




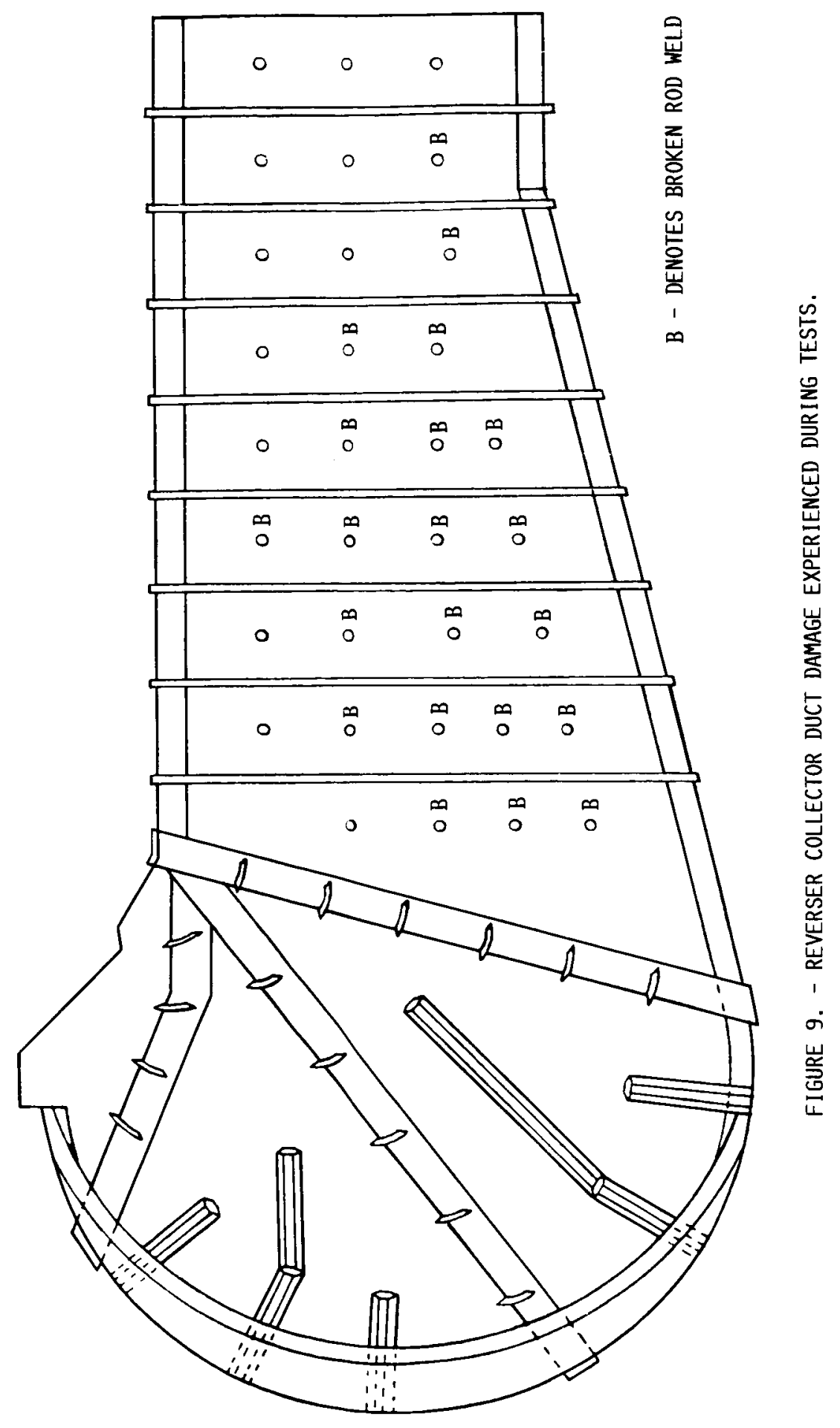



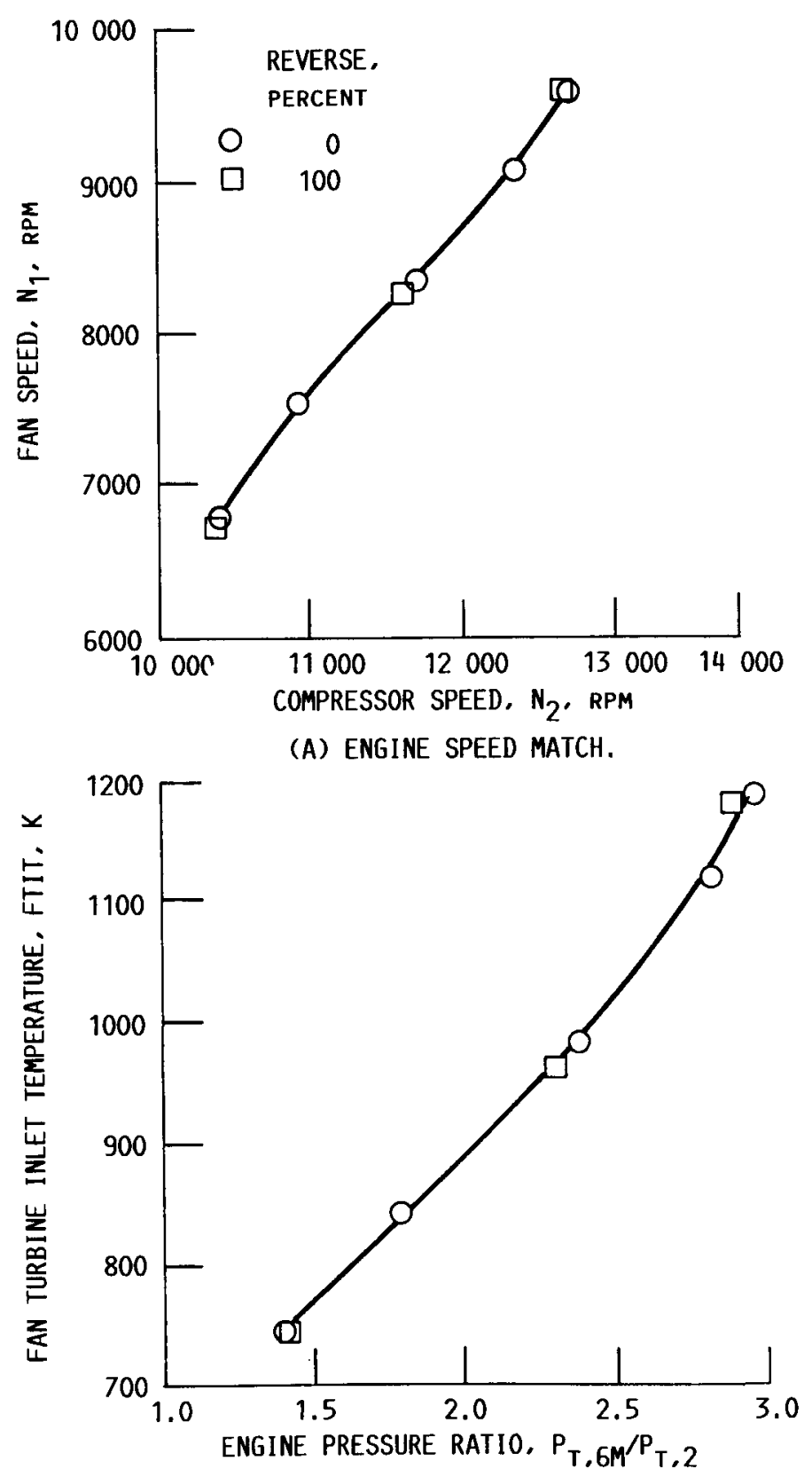

(B) FAN TURBINE INLET TEMPERATURE.

FIGURE 10. - EFFECT OF THRUST REVERSER OPERATION ON ENGINE PERFORMANCE: FLIGHT CONDITION - 12192 M. 0.8 MACH NUMBER. 


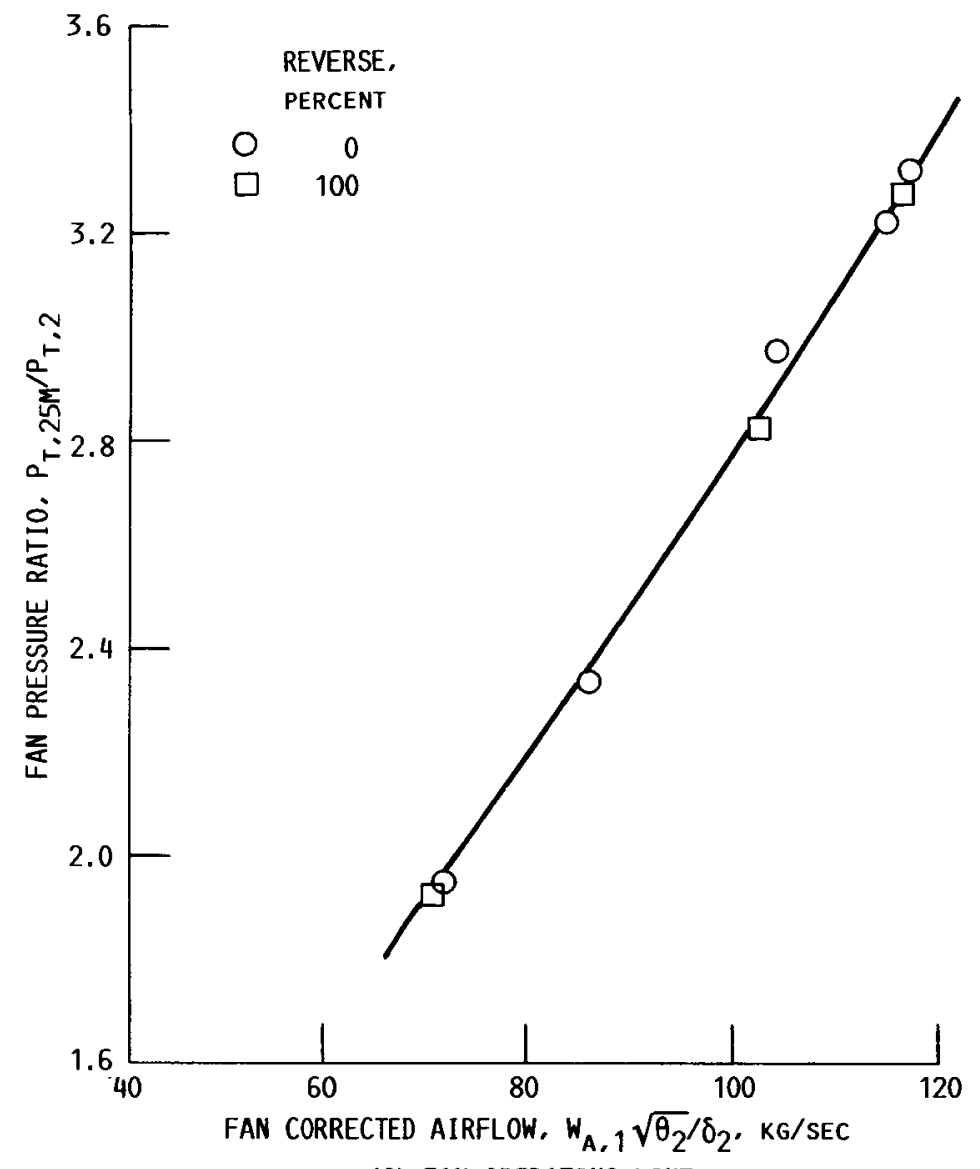

(C) FAN OPERATING LINE.

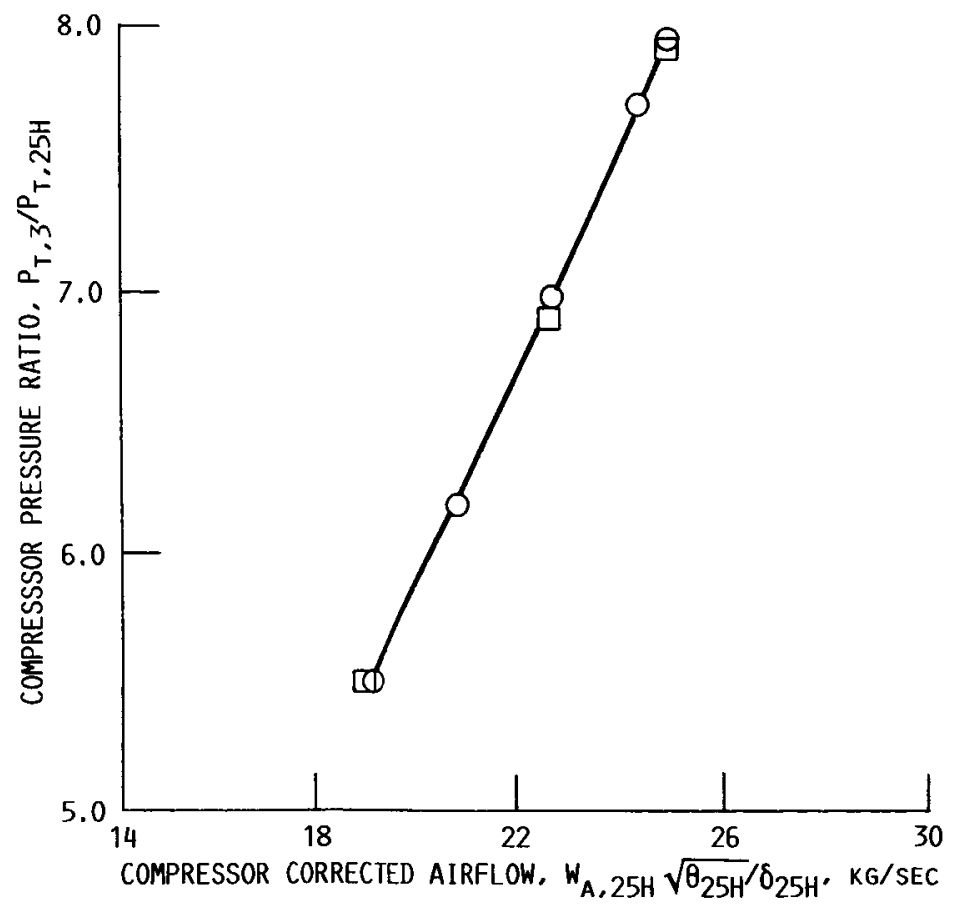

(D) COMPRESSOR OPERATING LINE.

FIGURE 10. - CONCLUDED. 

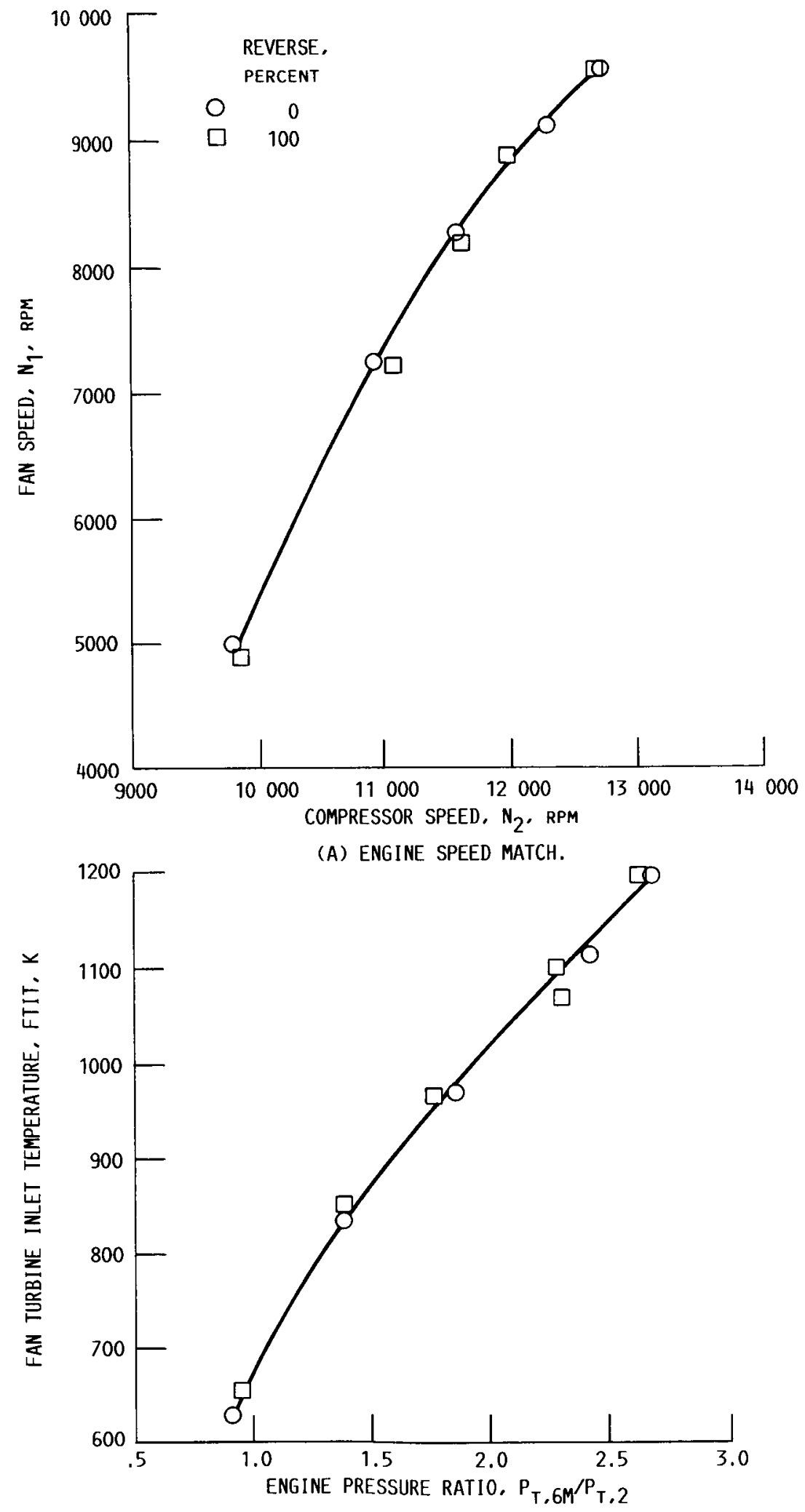

(B) FAN TURBINE INLET TEMPERATURE.

FIGURE 11. - EFFECT OF THRUST REVERSER OPERATION ON ENGINE PERFORMANCE: FLIGHT CONDITION $-7315 \mathrm{M}, 0.8 \mathrm{MACH}$ NUMBER. 

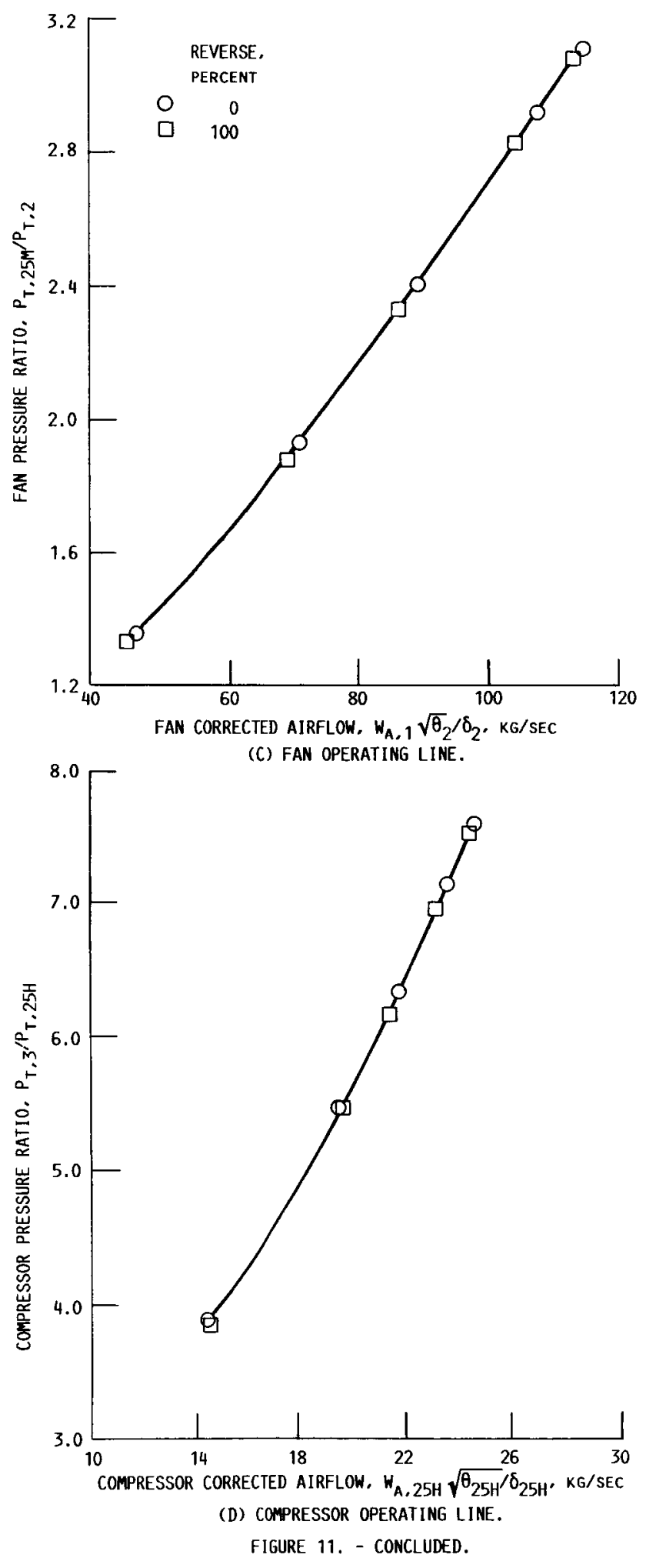

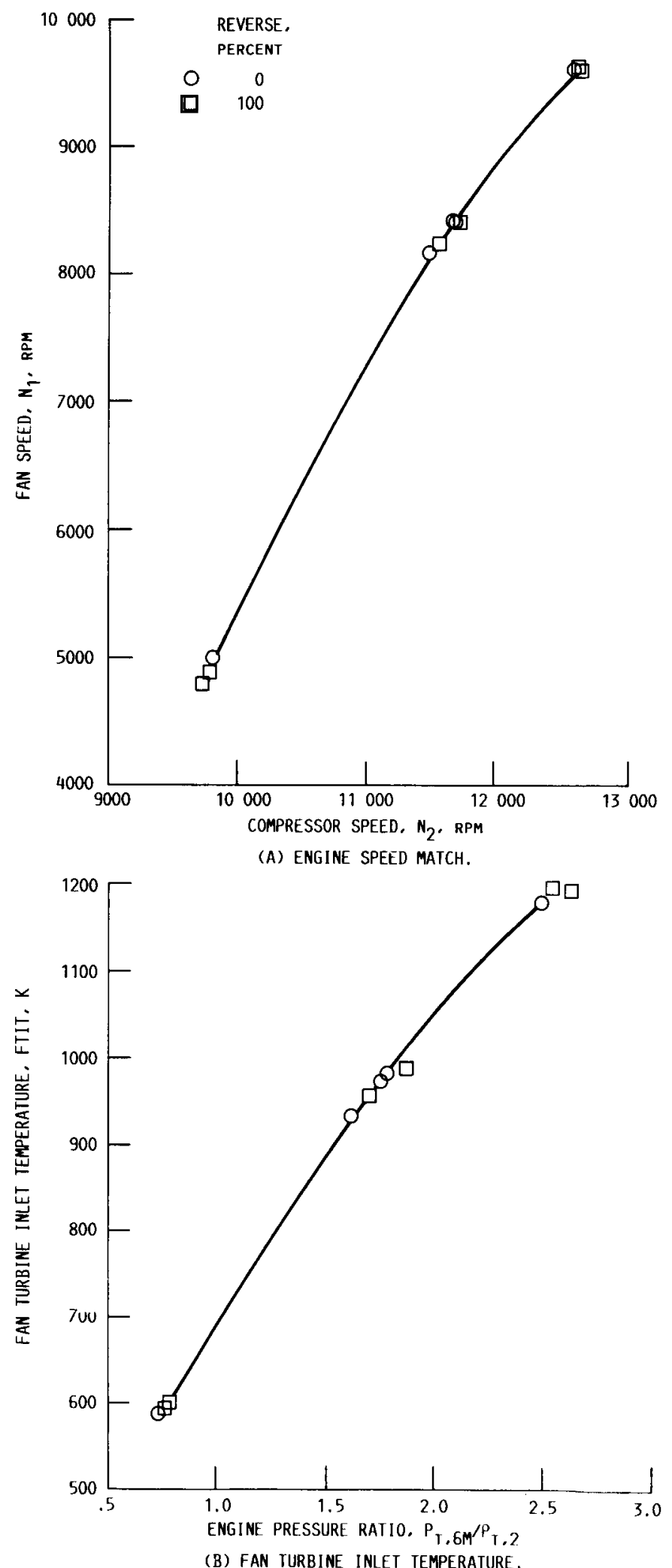

FIGURE 12. - EFFECT OF THRUST REVERSER OPERATION ON ENGINE PERFORMANCE: FLIGHT CONDITION - $9144 \mathrm{M}, 1.17 \mathrm{MACH}$ NUMBER. 

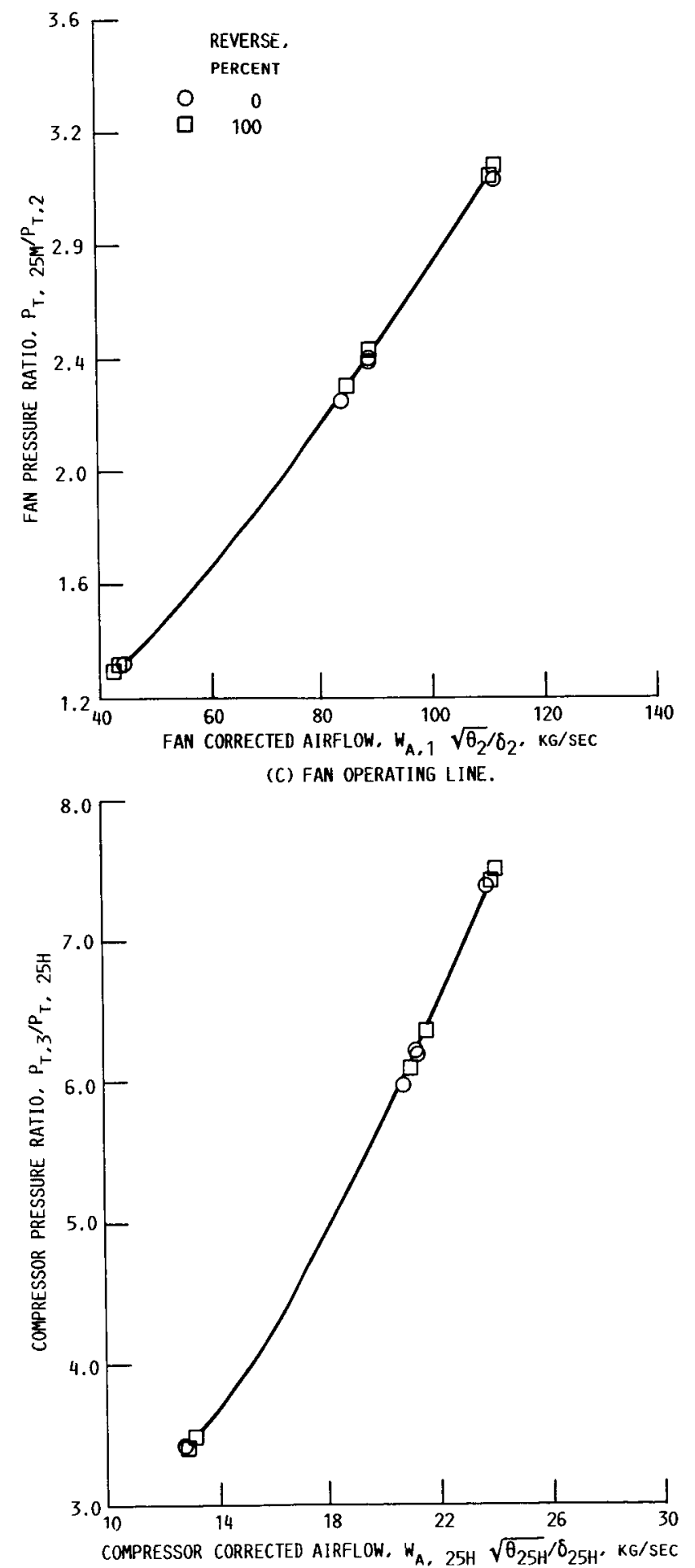

(D) COMPRESSOR OPERATING LINE.

FIGURE 12. - CONCLUDED. 

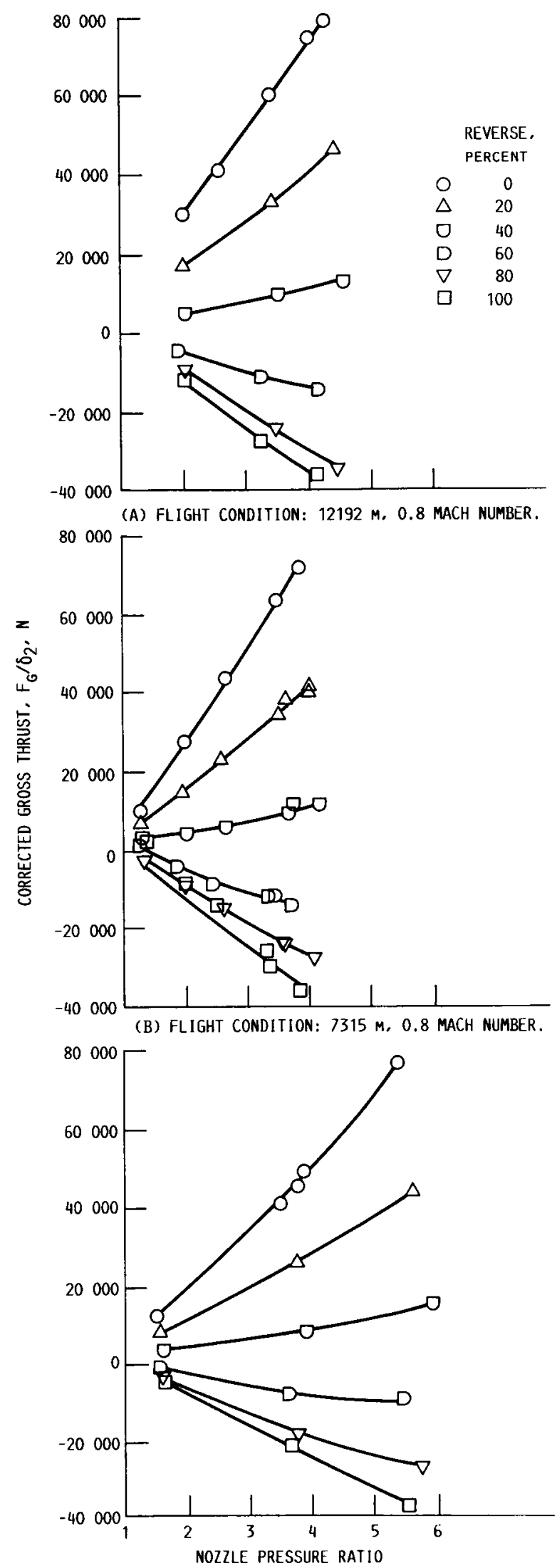

(C) FLIGHT CONDITION: $9144 \mathrm{M}, 1.17$ MACH NUMBER.

FIGURE 13. - EFFECT OF THRUST REVERSER OPERATION ON MEASURED GROSS THRUST. 


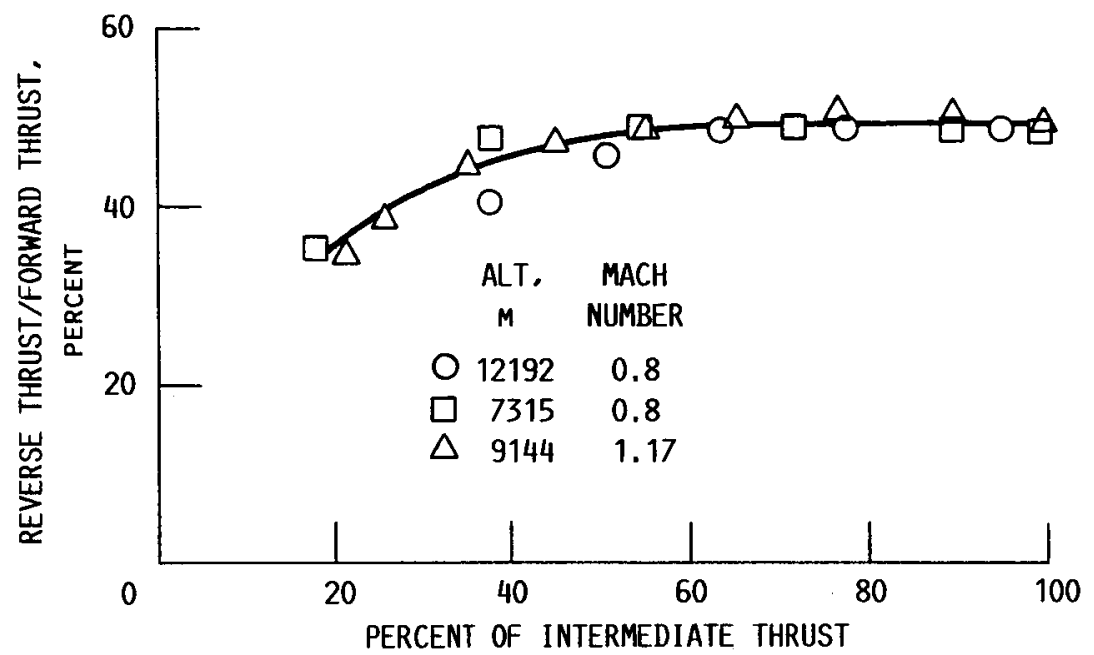

FIGURE 14. - REVERSE THRUST PERFORMANCE. 




"For sale by the National Technical Information Service. Springtield. Virginia 22161 